\title{
PERAN MAJELIS PENGAWAS DAERAH NOTARIS DALAM MENCEGAH TERJADINYA PELANGGARAN HUKUM OLEH NOTARIS DI KOTA PADANG
}

\author{
Dina Shabrina ${ }^{1}$, Azmi Fendri ${ }^{2}$, Frenadin Adegustara ${ }^{3}$ \\ Fakultas Hukum Universitas Andalas Padang ${ }^{123}$ \\ Email: bikintugasku@gmail.com
}

\begin{abstract}
The Regional Supervisory Council has a strategic role in maintaining the Notary profession in carrying out its position. This article aims to examine to what extent the role of the regional notary supervisory council in preventing violations of Notary law in Padang City. This study uses a juridical-empirical approach with data in the form of secondary data and primary data. This study focuses on several things about what factors cause legal violations by Notaries in Padang City, what is the role of the Regional Supervisory Council in preventing legal violations by Notaries in Padang City, and what actions are taken by the Regional Supervisory Council against Notaries who commit violation of the law by a Notary in Padang City. The results of the research study show that the factors that cause legal violations committed by notaries in the city of Padang are notaries who like to accept jobs that are not in accordance with the date the deed was made and the notaries often do not come face to face with clients, in preventing legal violations by notaries in the city. Padang, namely with the socialization and going directly to the field. Actions taken if there is a violation of the law by a Notary, namely carrying out an examination process in order to prove whether the Notary has committed a violation or not.
\end{abstract}

Keywords: Regional Supervisory Council, Notary, Law Violation

\begin{abstract}
Abstrak
Mejelis Pengawas Daerah memiliki peran strategis dalam menjaga profesi Notaris dalam menjalankan jabatannya. Artikle ini bertujuan untuk mengkaji sejauhmana peran majelis pengawas daerah notaris dalam mencegah terjadinya pelanggaran hukum Notaris di Kota Padang. Kajian ini menggunakan pendekatan yuridis-empiris dengan jenis data berupa data sekunder dan data primer. Kajian ini menfokuskan pada beberapa hal tentang faktor apa saja yang menyebabkan terjadinya pelanggaran hukum oleh Notaris di Kota Padang, bagaimana peran Majelis Pengawas Daerah dalam mencegah terjadinya pelanggaran hukum oleh Notaris di Kota Padang, dan tindakan apa yang dilakukan oleh Majelis Pengawas Daerah terhadap Notaris yang melakukan pelanggaran hukum oleh Notaris di Kota Padang. Hasil kajian penelitian menunjukkan bahwa faktor penyebab terjadinya pelanggaran hukum yang dilakukan oleh Notaris di Kota Padang adalah Notaris suka menerima pekerjaan yang tidak sesuai dengan tanggal yang dibuatnya akta tersebut dan Notaris sering tidak bertatap muka langsung dengan klien, dalam mencegah terjadinya pelanggaran hukum oleh Notaris di Kota Padang yaitu dengan
\end{abstract}


adanya sosialisasi dan langsung turun ke lapangan. Tindakan yang dilakukan jika adanya pelanggaran hukum oleh Notaris yaitu menjalankan proses pemeriksaan agar dapat membuktikan apakah Notaris tersebut melakukan pelanggaran atau tidak.

Kata Kunci: Majelis Pengawas Daerah, Notaris, Pelanggaran Hukum

\section{PENDAHULUAN}

Perkembangan zaman saat ini menuntut para subjek hukum mendapatkan kepastian dari setiap perbuatan hukumnya. Perbuatan hukum saat ini erat kaitannya dengan bisnis sehingga menjadi organ penggerak dalam perekonomian Negara. Negara memiliki tanggung jawab dalam memberikan kepastian hukum agar terwujudnya keadilan. Pada hubungan keperdataan, masyarakat menginginkan adanya jaminan kepastian, ketertiban dan perlindungan hukum.Alat bukti tertulis telah menjadi kebutuhan masyarakat dan diatur dalam Pasal 1868 Kitab Undang-Undang Hukum Perdata (KUH Perdata), "Suatu akta autentik adalah akta yang bentuknya ditentukan oleh undang-undang yang dibuat oleh atau dihadapan pegawai-pegawai umum yang berkuasa untuk itu ditempat akta tersebut dibuatnya".

Akta autentik memiliki kekuatan tetap dan sempurna, sehingga bersifat mutlak yang dibuat oleh pejabat yang berwenang. Notaris merupakan pejabat yang berwenang untuk membuat akta autentik.Akta autentik yang dibuat oleh notaris adalah alat bukti yang menentukan dengan jelas hak dan kewajiban seseorang dalam subjek hukum, guna menjamin adanya kepastian, ketertiban, dan perlindungan hukum. Notaris sebagai pejabat umum, merupakan salah satu organ Negara yang dilengkapi dengan kewenangan hukum untuk memberikan pelayanan hukum kepada masyarakat, teristimewa dalam pembuatan akta autentik sebagai alat bukti yang sempurna berkenaan dengan perbuatan hukum di bidang keperdataan (Yudara, 2006).

Notaris sebagai Pejabat Umum ditentukan di Pasal 1 angka (1) Undang-Undang Nomor 2 Tahun 2014 tentang Perubahan atas UndangUndang Nomor 30 Tahun 2004 tentang Jabatan Notaris, menyatakan "Notaris adalah pejabat umum yang berwenang untuk membuat akta autentik dan memiliki kewenangan lainnya sebagaimana dimaksud dalam Undang-Undang ini atau berdasarkan Undang-Undang lainnya." Selanjutnya kewenangan pejabat umum tersebut diatur dalam Pasal 15 Undang-Undang Jabatan Notaris.

Kewenangan yang melekat pada jabatan notaris ini membuat Negara mengatur terkait pengawasan dan sanksi bagi notaris yang melanggar peraturan pelaksanaan jabatan. Notaris harus tunduk pada Undang-Undang Jabatan Notaris, Kode etik notaris dan juga peraturan 
lain yang berkaitan denganjabatan Notaris. Peranan Notaris sebagai pejabat umum yang melayani pembuatan akta autentik bagi masyarakat untuk melindungi kepentingan masyarakat, maka dibutuhkan pengawasan dan pembinaan terhadap profesi notaris.Pengawasan terhadap notaris dilakukan Menteri yang dalam pelaksanaannya untuk melaksanakan pengawasan tersebut dibentuk Majelis Pengawasan.

Dasar keberadaan Majelis Pengawas diatur dalam Undang-Undang Nomor 2 Tahun 2014 tentang Jabatan Notaris. Pengawasan tersebut meliputi perilaku Notaris dan pelaksanaan jabatan Notaris.Dalam hal ini ditegaskan dalam Pasal 67 ayat (5) UUJN yang menyatakan "Pengawasan sebagaimana dimaksud pada ayat (1) meliputi perilaku notaris dan pelaksanaan jabatan notaris." Majelis Pengawas adalah suatu badan yang mempunyai kewenangan dan kewajiban untuk melaksanakan pembinaan dan pengawasan terhadap notaris.Pengawasan terhadap notaris dimaksudkan agar notaris dalam menjalankan tugas jabatannya wajib berdasarkan dan mengikuti peraturan perundang-undangan yang mengatur jabatan notaris.Notaris dalam menjalankan tugas jabatannya wajib berpegang dan berdasarkan peraturan perundang-undangan yang mengatur jabatan notaris secara melekat, artinya segla hal yang disebutkan dalam pearturan perundang-undangan yang mengatur jabatan notaris wajib diikuti.

Berdasarkan Pasal 68 Undang-Undang Jabatan Notaris disebutkan bahwa Majelis Pengawas terdiri dari Majelis Pengawas Daerah (MPD), Majelis Pengawas Wilayah (MPW), dan Majelis Pengawas Pusat (MPP). Majelis Pengawas Daerah menjadi tolak ukur paling penting dalam pengawasan terhadap notaris hal ini dikarenakan ruang lingkup pekerjaan Majelis Pengawas Daerah lebih dekat dengan keberadaan Notaris di wilayahnya sehingga pengawasan dan pembinaannya lebih mudah. Wewenang Majelis Pengawas Daerah diatur dalam UndangUndang Jabatan Notaris (UUJN), Peraturan Menteri Hukum dan Hak Asasi Manusia Republik Indonesia Nomor M.02.PR.08.10 Tahun 2004, dan Keputusan Menteri Hukum dan Hak Asasi Manusia Republik Indonesia Nomor M.39-PW.07.10. Tahun 2004. Pasal 70 Undang-Undang Jabatan Notaris (UUJN) mengatur wewenang Majelis Pengawas Daerah (MPD).

Kewenangan notaris sangatlah rentan dalam melakukan pelanggaran hukum. Peran majelis pengawas sangat penting guna menjaga profesi Notaris dalam menjalankan jabatannya. Penagakan hukum sangat dibutuhkan ketika adanya suatu kesalahan maka akan dijatuhkan sanksi yang harus diberikan kepada notaris yang bermasalah. Berdasarkan UUJN di atur bahwa ketika Notaris dalam menjalankan jabatannya terbukti melakukan pelanggaran, maka Notaris harus bertanggung jawab dengan cara dikenakan sanksi atau dijatuhi sanksi, berupa sanksi perdata, sanksi administrasi, sanksi pidana, kode etik 
jabatan Notaris atau kombinasi sanksi. Pasal-pasal yang memuat sanksi itu adalah Pasal 7 ayat (2); Pasal 16 ayat (11), ayat(12). Ayat (13); Pasal 17 ayat (2), Pasal 19 ayat (4); Pasal 32 ayat (4); Pasal 37 ayat (2); Pasal 54 ayat (2), dan Pasal 65A. Pelanggaran terhadap pasal-pasal tersebut dikenakan sanksi yang dimulai dari peringatan tertulis hingga pemberhentian tidak hormat.

Sementara itu, terhadap Notaris yang melakukan kesalahan sehingga menyebabkan kekuatan pembuktian akta berubah menjadi akta dibawah tangan, para pihak dapat meminta ganti rugi kepada Notaris yang bersangkutan. Hal itu dapat terjadi apabila Notaris melanggar Pasal 41 yaitu tidak melaksanakan Pasal 38, 39, dan 40; Pasal 44 ayat (5); Pasal 48 ayat (3), Pasal 49 ayat (4), Pasal 50 ayat (5), dan 51 ayat (4).

Di wilayah kerja Majelis Pengawas Daerah Notaris di Kota Padang berdasarkan data dari Majelis Pengawas Daerah Kota Padang sepanjang Tahun 2017 adanya laporan pelanggaran hukum yang dilakukan oleh Notaris dalam hal ini yaitu adanya pelanggaran yang dilakukan berupa Notaris tidak memberikan penyuluhan Hukum kepada para pihak sehingga menimbulkan kerugian, dan keberpihakan notaris pada salah satu pihak yang menimbulkan kerugian pada pihak lainnya, dan adanya rangkap jabatan ganda selain notaris.

Pelanggaran hukum yang dilakukan oleh notaris dapat mengakibatkan akta yang dibuatnya turun derajatnya menjadi akta di bawah tangan atau dimintakan pembatalan. Majelis Pengawas Daerah harus dapat melakukan pencegahan terhadap notaris untuk tidak melakukan perbuatan melawan hukum, karena profesi Notaris adalah sebagai pejabat umum yang ditunjuk Negara untuk menciptakan kepastian hukum dalam wilayah hukum perdata. Notaris harus menjunjung tinggi harkat martabat, serta menjalankan tugas jabatannya sesuai Undang-Undang Nomor 2 Tahun 2014 tentang Jabatan Notaris dan Undang-Undang yang berlaku sehubungan dengan profesi Notaris.

\section{METODE PENELITIAN}

Pendekatan masalah yang digunakan dalam penelitian ini adalah pendekatan yuridis empiris, yaitu suatu penelitian di samping melihat aspek hukum positif juga melihat seperti apa penerapan dilapangan dan masyarakat (Buchanan et al., 2014). Adapun penelitian ini termasuk dalam jenis penelitian lapangan. Sumber data yang digunakan dalam penelitian ini adalah data primer dan data sekunder. Data primer didapatkan melalui wawacara secara langsung dengan Majelis Pengawas Daerah Notaris di Kota Padang dan Notaris, sedangkan data sekunder berupa 1) bahan hukum primer yaitu peraturan perundangan-undangan seperti Undang-Undang Dasar Negara Republik Indonesia Tahun 1945, UndangUndang Nomor 30 Tahun 2004 tentang Jabatan Notaris, Undang-Undang 
Nomor 2 Tahun 2014 tentang Perubahan Atas Undang-Undang Nomor 30 Tahun 2004 tentang Jabatan Notaris, dan Kitab Undang-Undang Hukum Perdata; 2) bahan hukum sekunder berupa literasi kepustakaan seperti buku-buku, artikel hukum dan lain-lain; 3) bahan hukum tersier berupa kamus hukum,dan bahan-bahan hukum yang mengikat khususnya dibidang kenotariatan.

Teknik pengumpulan data yang digunakan dalam penelitian ini berupa kepustakaan, observasi, dan wawancara. Semetara itu, metode analisis data yang digunakan adalah diskriptif kualitatif yaitu uraian terhadap data dianalisis berdasarkan peraturan perundang-undangan dan pendapat para ahli kemudian dipaparkan dengan kalimat yang sebelumnya telah dianalisis, menafsirkan dan menarik kesimpulan sesuai dengan permasalahan yang dibahas.

\section{PEMBAHASAN}

\section{Faktor yang Menyebabkan Terjadinya Pelanggaran Hukum}

Pelanggaran-pelanggaran yang banyak dilakukan oleh Notaris pada prinsipnya bukan ketidaktahuan notaris akan adanya larangan tersebut. Tetapi, pelanggaran terjadi karena rendahnya kesadaran moral dan etika Notaris dalam menjalankan jabatannya. Berdasarkan dari data yang penulis dapatkan baik dari hasil wawancara ataupun dari data tertulis dari anggota Majelis Pengawas Daerah Kota Padang sepanjang Tahun 2017 adanya laporan pelanggaran hukum yang dilakukan oleh Notaris dalam hal ini yaitu adanya pelanggaran yang dilakukan berupa Notaris tidak memberikan penyuluhan Hukum kepada para pihak sehingga menimbulkan kerugian, dan keberpihakan notaris pada salah satu pihak yang menimbulkan kerugian pada pihak lainnya, dan adanya rangkap jabatan ganda selain notaris.

Terlepas dari semua bentuk pelanggaran hukum yang dilakukan Oleh Notaris, penulis tertarik melakukan penelitian mengenai Peran Majelis Pengawas Daerah dalam mencegah terjadinya pelanggaran hukum oleh Notaris di Kota Padang dan berdasarkan hasil wawancara dengan seorang anggota Majelis Pengawas daerah Kota Padang ibuk Desmawita beliau mengatakan bahwa salah satu faktor penyebab terjadinya pelanggaran hukum yang dilakukan oleh Notaris di Kota Padang adalah Notaris suka menerima pekerjaan yang tidak sesuai dengan tanggal yang dibuatnya akta tersebut dan Notaris sering tidak bertatapmuka langsung dengan klien, Selanjutnya beliau menyampaikan bahwa hal tersebut adalah salah satu pemicu Notaris melakukan pelanggaran hukum (Mejelis Pengawas Daerah, Wawancara: 2018). 
Tabel Pelanggaran yang dilakukan Notaris Tahun 2017-2018

\begin{tabular}{|c|l|}
\hline Nomor & \multicolumn{1}{|c|}{ Pelanggaran yang dilakukan Notaris } \\
\hline 1. & $\begin{array}{l}\text { Notaris tidak memberikan penyuluhan Hukum kepada para } \\
\text { pihak sehingga menimbulkan kerugian. }\end{array}$ \\
\hline 2. & $\begin{array}{l}\text { Notaris suka menerima pekerjaan yang tidak sesuai dengan } \\
\text { tanggal yang dibuat dalam akta tersebut. }\end{array}$ \\
\hline 3. & $\begin{array}{l}\text { Belum pernah mengirimkan laporan bulanan ke kantor } \\
\text { Wilayah maupun ke MPD. }\end{array}$ \\
\hline 4. & $\begin{array}{l}\text { Beberapa buku Protokol pendamping yang belum di paraf, } \\
\text { diberi Nomor dan dicap oleh MPD. }\end{array}$ \\
\hline 5. & $\begin{array}{l}\text { Ruangan Notaris yang tidak sesuai dengan aturan Perundang- } \\
\text { Undangan }\end{array}$ \\
\hline 6. & Minuta Akta yang tidak diberi stempel. \\
\hline 7. & Akta yang tidak ditanda tangani \\
\hline 8. & $\begin{array}{l}\text { Minuta akta yang tidak ada nama Notaris dan nama saksi serta } \\
\text { stempel Notaris. }\end{array}$ \\
\hline
\end{tabular}

Sumber: Majelis Pengawas Daerah Kota Padang.

Berdasarkan hasil wawancara penulis dengan salah satu Notaris di Kota Padang menyebutkan bahwa faktor lain yang menyebabkan Notaris melakukan pelanggaran adalah Notaris terlalu percaya diri dan tidak memiliki keinginan untuk bergabung dengan organisasi Notaris, dimana Organisasi Notaris adalah suatu wadah bagi Notaris untuk berbagi informasi, dan tidak adanya apresiasi dari Notaris terhadap sosialisasi yang dilakukan Majelis Pengawas Daerah, dan sebagian Notaris masih beranggapan bahwa Majelis Pengawas Notaris lah yang menjerumuskan mereka, padahal Majelis Pengawas Notaris lah yang melindungi martabat mereka sebagai Notaris, lalu Notaris yang baru tidak mau berdiskusi dan bertanya kepada Notaris lainnya yang sudah lebih banyak pengalamannya (Mejelis Pengawas Daerah, Wawancara: 2018).

Menurut Muhammad (2009) alasan-alasan mendasar mengapa Notaris cenderung melakukan pelanggaran Hukum dan Kode Etik:

1. Pengaruh sifat kekeluargaan

Salah satu ciri kekeluargaan itu memberi penghargaan yang sama terhadap anggota keluarga, dan ini dipandang adil. Perlakuan terhadap orang yang bukan anggota keluarga akan lain sifatnya. Hal ini berpengaruh terhadap perilaku profesionalisme hukum yang terikat pada kode etik profesi yang seharusnya memberi perlakuan yang sama terhadap klien.Dan seharusnya masalah keluarga dipisahkan dengan masalah profesi, dan ini adalah adil.Karena diharapkan Notaris dapat menajalankan jabatannya secara professional tanpa melibatkan adanya keterikatan karena adanya 
hubungan darah atau keluarga.Mengenai masalah ini cenederung kedalam peromohonan pembuatan akta oleh klien, baik klien itu merupakan anggota keluarga atau bukan, Notaris harus bertindak secara profesioanal tanpa membedakan mereka. Dengan cara demikian, Notaris tidak dapat melakukan pelanggaran hukum.

2. Pengaruh jabatan

Salah satu ciri jabatan adalah bawahan menghormati dan taat pada atasan dan ini adalah ketentuan Undang-Undang kepegawaian. Fungsi eksekutif terpisah dengan fungsi yudikatif.Seharusnya masalah jabatan dipisah dengan masalah profesi dan ini adalah adil.Sebagai seorang professional haruslah bekerja dengan fungsional.

3. Pengaruh Konsumerisme

Peningkatan kebutuhan tidak sebanding dengan penghasilan yang diterima oleh professional. Hal ini mendorong professional berusaha memperoleh penghasilan yang lebih besar melalui jalan pintas dan terobosan profesioanal, yaitu dengan mencari imbalan jasa dari pihak yang dilayaninya.

4. Karena lemah iman

Salah satu syarat menjadi professional itu adalah taqwa kepada Tuhan yang Maha Esa, yaitu melaksanakan perintah dan menjahui larangannya. Ketaqwaan ini adalah dasar Moral manusia. Jika manusia mempertbal iman dan taqwa, maka didalam diri akan tertanam moral yang menjadi rem untuk berbuat buruk.

Dengan demikian dalam profesi Notaris, alasan-alasan tersebut kecenderungan Notaris dalam melakukan pelanggaran. Untuk menjawab permasalahan di atas penulis menggunakan teori kewenangan. Komponen pengaruh merupakan penggunaan wewenang dimaksud untuk mengendalikan prilaku subyek hukum, komponen dasar hukum bahwa wewenang itu selalu harus dapat ditunjuk dasar hukumnya. Hal ini bisa menjadi pedoman bagi Notaris untuk menjalankan jabatannya sesuai dengan UUJN dan Kode Etik Notaris dan tidak melakukan pelanggaran Hukum.

Tindakan Dilakukan Oleh Majelis Pengawas Daerah Terhadap Notaris Yang Melakukan Pelanggaran Hukum oleh Notaris di Kota Padang

Pengawasan yang dimaksud merupakan kegiatan yang bersifat preventif dan represif. Bersifat preventif mengandung makna suatu proses pembinaan, sedangkan bersifat represif mengandung makna yang melakukan penjatuhan sanksi terhadap Notaris dalam pelaksanaan jabatannya apabila terbukti melakukan pelanggaran terhadap UndangUndang Nomor 30 Tahun 2004 tentang Jabatan Notaris beserta Perubahannya Undang-Undang Nomor 2 Tahun 2014 dan pelanngaran terhadap Kode Etik Notaris. 
Fungsi pembinaan ditujukan agar yang diawasi yaitu Notaris selalu diingatkan untuk selalu memahami dan oleh karena mematuhi aturan yang baik yang hanya tercantum dan diatur dalam Kode Etik Notaris maupun ketentuan dalam Peraturan Perundang-Undangan yang berlaku.Semua itu dilandasi oleh Undang-Undang atau Makna Sumpah Jabatan yang diucapkan dan disaksikan oleh saksi dunia yaitu Pejabat Pelaksana Sumpah dan para saksi yang khusus didatngkan untuk itu.Tidak lupa bahwa sumpah jabatan Notaris tersebut juga disaksikan oleh Allah SWT, Tuhan Yang Maha Esa, Maha Mengetahui dan Maha Mengawasi.Dalam suasana empati ini diharapkan Notaris sudah mempunyai sistem pertahan diri untuk menangkal segala sesuatu hal yang dapat membuat jatuhnya kehormatan dan martabat Notaris (Wawancara dengan Mejelis Pengawas Daerah Kota Padang, 4 Mei 2018).

Fungsi pengawasan kepada Notaris ditujukan agar dalam menjalankan jabatannya Notaris senantiasa memenuhi ketentuanketentuan Perundang-Undangan yang berlaku, dan kode etik Notaris karena bila seorang Notaris terbukti melakukan pelanggaran akan dikarenakan sanksi. Majelis Pengawas Daerah Notaris dibentuk berdasarkan UUJN Pasal 1 ayat (1) dan Pasal 69 yang terdiri dari 3 unsur yaitu Notaris, akademisi dan Pemerintahan sementara Ikatan Notaris Indonesia merupakan lembaga yang terbentuk dari organisasi profesi Notaris yang mengatur permasalahan Kode Etik yang seluruh anggoatannya hanya Notaris, tercantum pada Pasal 82 UUJN perihal Notaris berhimpun pada satu wadah Organisasi Notaris yang dimaksud adalah Ikatan Notaris Indonesia.

Merujuk dari permasalahan tersebut diatas jika Notaris terbukti melanggar kewajiban Pasal 16 UUJN, larangan Pasal 17 UUJN serta Kode Etik maka dapat diajtuhkan sanksi. Kewenangan Majelis Pengawas Daerah (MPD) telah ditentukan dalam Pasal 70 UUJN tentang jabatan Notaris.Selanjutnya kewajiban Majelis Pengawas Daerah telah ditentukan dalam Pasal 71 UUJN.

Berdasarkan Pasal 70 ayat 2 UUJN yaitu Majelis Pengawas Daerah Kota Padang memiliki kewenangan melakukan pemeriksaan terhadap Protokol Notaris secara berkala 1 (satu) kali dalam 1 ( satu) tahun setiap waktu yang dianggap perlu. Salah satu bentuk tanggung jawab Notaris adalah berkaitan dengan Protokol Notaris.Dalam Pasal 1 angka 13 UUJN disebutkan bahwa "Protokol Notaris adalah kumpulan dokumen yang merupakan arsip negara yang harus disimpan dan dipelihara oleh Notaris sesuai dengan ketentuan peraturan perundang-undangan." Dokumendokumen yang termasuk protokol Notaris tersebut dijabarkan dalam penjelasan Pasal 62 UUJN. Protokol Notaris tersebut harus diserahkan kepada pihak lainnya menurut ketentuan yang diatur didalam Pasal 62 
UUJN yang telah ditentukan penyebab dilakukannya penyerahan protokol Notaris (Salim, 2015).

Sebelum dilakukannya penyerahan protokol Notaris tersebut bagi Notaris yang ingin pindah tempat kedudukan terlebih dahulu harus memenuhi syarat-syarat sebagaimana diatur dalam Pasal 23 UUJN. Protokol Notaris merupakan bagian dari administrasi kantor Notaris yang mempunyai fungsi dan peran yang sangat penting agar Notaris dapat menjalankan jabatan yang baik dan benar. Oleh karena itu Protokol Notaris sebagai arsip Negara harus ditata dan dikelola dengan baik.Dimana protokol Notaris diawasi oleh Majelis Pengawas Notaris yaitu Majelis Pengawas Daerah.Majelis Pengawas Daerah mempunyai kewenangan yang diatur dalam Pasal 70 UUJN.

Berdasarkan data yang penulis dapatkan bahwa Majelis Pengawas Daerah Wilayah Padang yang meliputi Kota Padang dan Pesisir Selatan Pada Tahun 2017 telah melakukan pemeriksaan terhadap Protokol Notaris. Di Kota Padang pada Tanggal 23 Agustus 2017 Majelis Pengawas Daerah Kota Padang melakukan pemeriksaan Protokol Notaris di beberapa tempat yakni Notaris berinisial EFS, Notaris N, dan Notaris HVP. di Kabupaten Pesisir Selatan pada Tanggal 04-05 Mei Tahun 2017 Majelis Daerah Notaris Padang telah melakukan pemeriksaan protokol Notaris di beberapa tempat yakni:

1. Notaris berinisial NB, dan terdapat beberapa hal yang ditemukan diantaranya:

a. Belum pernah pengirimkan laporan bulanan ke Kantor Wilayah maupun kepada MPD N Padang

b. Beberapa buku protocol pendamping belum di paraf, diberi nomor dan dicap oleh MPD N Padang

c. Ruangan Notaris tidak memenuhi syarat sesuai dengan aturan Perundang-Undangan yang berlaku seperti tidak adanya ruangan tamu dan ruang Notaris

d. Pada buku surat dibawah tangan yang disahkan ada terdapat kesalahan penulisan pada buku, agar lembaran dimaksud di tutup atau di lem.

2. Notaris YAI, dan terdapat beberapa hal yang ditemukan diantaranya:

a. Belum pernah pengirimkan laporan bulanan ke Kantor Wilayah maupun kepada MPD N Padang

b. Semua buku protokol pendamping belum diparaf, diberi nomor dan dicap oleh MPD N Padang

c. Masih banyak terdapat akta yang telah diselesaikan belum dicatat pada buku daftar akta

d. Pada minuta akta tidak diberi stempel.

3. Notaris E, dan terdapat beberapa hal yang ditemukan diantaranya: 
a. Banyaknya akta Tahun 2014-2015 yang tidak di tanda tangani dan tidak distempel.

b. Banyak ditemui akta yang sudah diberi nomor kemudian dinyatakan batal yang seharusnya diberi keterangan bahwa nomor tersebut dibatalkan pada buku daftar akta kalau memang benarbenar dibatalkan.

c. Uji petik akta nomor 21 tangal 06 Februari 2015 belum ditanda tangani oleh Notaris yang bersangkutan.

d. Akta yang sudah keluar belum dipindahkan ke buku reportarium.

4. Notaris YA, sebagai Notaris pengganti dari Notaris M, dan terdapat beberapa hal yang ditemukan diantaranya:

a. Pada buku daftar akta terdapat nomor akta yang dikosngkan sementara akta belum keluar

b. Terdapat minuta akta yang tidak ada nama Notaris dan nama saksi serta stempel Notaris

c. Buku warmeking masih menggunakan buku sementara, untuk segera buku tersebut diganti dan di paraf, stempel dan diberi nomor oleh MPD N Padang

d. Buku protokol pendamping lainnya yang berdasarkan peraturan Perundang-Undangan belum ada.

Berdasarkan hasil wawancara peneliti dengan salah satu Majelis Pengawas daerah Kota Padang dari pemeriksaan lapangan yang dilakukan Oleh Majelis Pengawas Daerah terhadap Protokol Notaris maka tindakan yang dilakukan oleh Majelis Pengawas Daerah yaitu maka Majelis Pengawas Daerah Notaris di Kota Padang akan membentuk Majelis Pemeriksa untuk menjalankan proses pemeriksaan agar dapat membuktikan apakah Notaris tersebut melakukan pelanggaran atau tidak. Jika memamg Notaris yang bersangkutan terbukti melakukan pelanggaran jabatan maka akan diberikan sanksi berupa peringatan tertulis kepada Notaris yang bersangkutan tidak mengulangi perbuatannya lagi dan jika mengulanginya lagi kasus pelanggaran jabatan dapat direkomendasikan ketingkat Majelis Pengawas Wilayah dan Majelis Pengawas Pusat sehingga dapat dijatuhkan sanksi yang lebih berat seperti pemberhentian sementara (Wawancara dengan Majelis Pengawas Daerah Kota Padang, 4 Mei 2018).

Berdasarkan data yang penulis dapatkan pemeriksaan berdasarkan tingkatan Mejelis Pengawas Daerah yaitu:

1. Laporan pengaduan dari masyarakat atas dugaan pelanggaran jabatan dan kode etik notaris. Disampaikan melalui sekretariat MPD. Ketua Majelis Pengawas Daerah membentuk majelis pemeriksa daerah (3 orang/masing-masing unsur, dan dibantu oleh 1 orang sekretaris).

2. Pemanggilan kepada para pihak (secara tertulis). Pemeriksaan (bersifat tertutup untuk umum). 
3. Majelis Pemeriksa Daerah wajib menyelesaikan pemeriksaannya dan hasilnya disampaikan kepada para pihak dalam jangka waktu paling lambat 30 (tiga puluh) hari kalender sejak laporan diterima.Hasil pemeriksaan Majelis Pemeriksan Daerah dituangkan dalam berita acara pemeriksaan dan disampaikan kepada MPW dan tembusannya kepada para pihak (pelapor dan terlapor), MPP, Pengurus Daerah Ikatan Notaris Indonesia.

Berdasarkan data yang penulis dapatkan pemeriksaan berdasarkan tingkatan Mejelis Pengawas wilayah (MPW) yaitu

1. MPW menerima rekomendasi hasil pemeriksaan mpd

2. Ketua MPW membentuk majelis pemeriksa wilayah

3. Majelis pemeriksa wilayah melakukan pemeriksaan terhadap hasil pemeriksaan mpd (pemeriksaan tertutup untuk umum)

4. Majelis pemeriksa wilayah berwenang melakukan pemanggilan kepada para pihak untuk didengarkan keterangannya (7 hari kalender sejak berkas diterima)

5. Pembacaan putusan (dalam kurun waktu 30 hari kalender sejak berkas diterima), Putusan memuat :

a. Alasan dan Pertimbangan yang cukup yang dijadikan dasar untuk menjatuhkan putusan

b. Putusan ditandatangani oleh Ketua, Anggota dan Sekretaris Maje;is Pemeriksa Wilayah

c. Dalam hal laporan tidak dapat dibuktikan maka putusan menyatakan laporan di tolak dan terlapor direhabilitasi nama baiknya;

d. Jika laporan masyarakat dapat dibuktikan mala terlapor (notaris) dijatuhi sanksi sesuai dengan tingkat pelanggaran yang dilakukan

e. Salinan Putusan Majelis Pemeriksa Wilayah disampaikan kepada : Menteri, Pelapor, Terlapor, MPD, PP INI, dalam kurun waktu 30 hari kalender terhitung sejak putusan diucapkan. (Jika keberatan dengan putusan mpw maka dapat dilakukan upaya hukum banding kepada mpp dalam kurun waktu 14 hari kalender sejak banding dinyatakan).

Untuk menjawab permasalahan ketiga ini penulis menggunakan teori kepastian hukum karena menurut teori ini hukum dapat dikatakan sebagai sebuah sistem norma dimana norma-norma itu sendiri berisi aturan-aturan yang menjadi pedoman baik individu ataupun kelompok dalam menjalankan kehidupan bermasyarakat. Mengacu kepada permasalahan diatas, adanya tercipta aturan-aturan yang mengikat hanya saja masih terjadi pelannggaran hal ini dapat berindikasi dari efektif penegakan dan penindakan yang dilakukan Majelis Pengawas Daerah Kota Padang dalam melakukan penindakan pelanggaran hukum yang dilakukan oleh Notaris. 


\section{Pengawas Daerah dalam Mencegah Terjadinya Pelanggaran Hukum Oleh Notaris di Kota Padang}

Pelaksanaan tugas jabatan Notaris sebagai pejabat umum yang telah disahkan untuk mengabdi dan taat pada hukum diwujudakan lewat kepatuhan pada norma dan etika. Seorang Notaris harus memiliki kemampuan professional tinggi dengan memperhatikan norma hukum yang dilandasi dengan intgerasi moral, keluhuran martabat dan etika profesi sehingga kepercayaan terhadap jabatan notaris tetap terjaga. Sudah sewajarnya bila masyarakat muncul harapan dan tuntutan bahwa pengembanan dan pelaksaan profesi notaris selalu dijalankan dan taat pada norma hukum dan etika profesi.

Tuntutan ini menjadi faktor penentu unutk mempertahankan citranya sebagai pejabat umum. Perilaku professional Notaris lebih dititikberatkan pada kemampuan seorang notaris itu secara kemampuan/skill, professional Notaris terletak pada produk-produk akta yang dibuatnya, dapat mengakomodir keinginan para pihak yang membuatnya, memenuhi syarat-syarat dalam pembuatan akta, memiliki kekuatan pembuatan yang kuat, pendek kata kata yang dibuat oleh Notaris mampu menjadi alat bukti yang sempurna saat diperlukan sebagai alat bukti.

Sedangkan moral akhlak, attitude Notaris adalah sikap mental yang harus dimiliki Notaris dalam menunjang profesioanlya. Sebuah professional tanpa akhlak akan menjadi Notaris yang terlalu"money oriented" dalam menjalankan jabatannya. Perlu diingat bahwa Notaris adalah pejabat umum yang diangkat dan diberhentikan oleh Negara, sehingga harus memberikan pelayanan yang baik kepada semua lapisan masyarakat tanpa membeda-bedakan strata atau golongan tertentu dan bukan mengatasdasarkan karena pertimbangan uang semata.

Dalam menjalankan jabatannya Notaris harus mematuhi seluruh kaedah moral yang telah hidup dan berkembang dimasyarakat. Selain dari adanya tanggung kawab dari etika profesi, adanya integritas dan moral yang baik merupakan persyaratan penting yang harus dimilki Notaris. Oleh karena itu, Notaris harus senantiasa menjalankan jabatannya sesuai dengan UUJN dan Kode Etik Notaris.

Selanjutnya didalam menjalankan tugas dan jabatannya Notaris juga memiliki kewajiban yang harus ia patuhi dan jalani yang tertera pada Pasal 16 UUJN. Sebagai Pejabat Umum Notaris dalam menjalankan jabatannya juga memiliki larangan yang harus ia patuhi dan tidak dilakukan sebagai mana tertera pada Pasal 17 ayat (1) UUJN. Selain itu kewenangan Majelis Pengawas Daerah (MPD) telah ditentukan dalam Pasal 70 UUJN tentang jabatan Notaris.Kewajiban Majelis Pengawas Daerah telah ditentukan dalam Pasal 71 UUJN. 
Berdasarkan hasil wawancara dengan salah satu Majelis Pengawas Daerah Kota Padang, masih ada Notaris yang melakukan pelanggaran hukum kasus pelanggaran Jabatan notaris yang dilaporkan dan itu terjadi sepanjang tahun 2017. Salah satu pelanggaran kode etik yang terjadi di daerah Majelis Pengawas daerah Kota Padang Pada tahun 2017 berdasrkan Berita Acara Pemeriksaan Nomor W3.HM.07.01.MPD.PDG-44 Tahun 2017 dan Berita Acara Pemeriksaan Nomor 04/BAP/MPDN, kedua Notaris melakukan pelanggaran terhadap ketentuan Pasal 15 huruf e Undang-Undang Nomor 30 Tahun 2004 dan Undang-Undang Nomor 2 Tahun 2014 Tentang Jabatan Notaris, dimana Notaris tersebut tidak melakukan penyuluhan Hukum kepada masyarakat. Akibat dari pelanggaran tersebut menyebabkan kliennya mengalami kerugian dimana terjadi peralihan hak dari pihak klien kepada pihak lain. Dan peralihan tersebut dilakukan oleh Notaris tersebut tanpa sepengetahuan dari pemegang hak melalui perantara calo (Wawancara dengan Majelis Pengawas Daerah Kota Padang, 4 Mei 2018).

Salah satu anggota Majelis Pengawas Daerah kota Padang menguraikan beberapa upaya yang dilakukan oleh Majelis Pengawas Daerah Kota Padang dalam mencegah terjadinya pelanggaran Hukum oleh Notaris di Kota Padang, pertama dengan menerapkan pengawasan yang bersifat preventif yaitu pengawasan yang dilakukan sebelum dikeluarkan suatu keputusan/ ketetapan pemerintah yang disebut pengawasan apriori, yang akan ditetapkan dengan peraturan pemerintah yaitu dengan adanya sosioalisasi dan penyuluhan hukum terhadap Notaris dan Represif yaitu pengawasan yang dilakukan sesudah dikeluarkannya keputusan/ketetapan pemerintah atau sesudah adanya pelanggaran tersebut yaitu memberikan sosialisasi dan penyuluhan ketika sidang terhadap kasus pelanggaran yang dilakukan oleh Notaris, sehingga bersifat korektif dan memulihkan sutau tindakan yang keliru, disebut juga pengawasan aposteriori. Kedua dalam penjelasannya, salah satu anggota Majelis Pengawas Daerah Notaris Kota Padang juga melakukan sosialisasi kepada pihak-pihak yang terkait dengan profesi Notaris di bawah kewenangannya.

Berdasarkan data yang penulis dapatkan dari MPD pada tanggal 13- 14 Februari 2018 MPD melakukan sosialisasi dengan topik "Sosialisasi Layanan Kenotariatan", dan Tema yaitu "Melalui Sosialisasi Layanan Kenotariatan ini mari kita tingkatkan Sinergitas Majelis Kehormatan Notaris, Majelis Pengawas Wilayah dan Majelis Pengawas Wilayah dalam rangka perbaikan kualitas Notaris di Sumatera Barat."

Sosialisasi ini bertujuan untuk:

1. Menggali permasalahan dan kendala yang ditemukan oleh notaris dalam memberikan pelayanan kepada masyarakat; 
2. Memberikan dan mencarikan solusi efektif serta penyamaan persepsi dalam menghadapi permasalahan dan kendala yang ditemukan oleh notaris;

3. Menyebarluaskan informasi mengenai pengawasan, pembinaan dan pelayanan kenotariatan oleh pemerintah.

Selain itu sosialisasi bertujuan agar masyarakat sebagai pengguna jasa Notaris dapat lebih mengetahui hak dan kewajibannya sehingga apabila dikemudian hari terjadi pelanggaran yang dilakukan oleh Notaris dapat melaporkan pelanngaran tersebut kepada Majelis Pengawas Daerah. Salah satu Notaris di Kota Padang, mengatakan bahwa Majelis Pengawas Daerah memang selalu rutin melakukan sosialisasi dan penyuluhan hukum kepada Notaris di Kota Padang dan minimal satu kali dalam satu tahun dan biasanya Majelis Pengawas Daerah selalu memberikan sosialasi di setiap akhir acara Pengurusan Wilayah, atau acara yang dibuat oleh Mejelis Pengawas Daerah. Berkaitan dengan salah satu upaya Majelis Pengawas Daerah Kota Padang dalam mencegah terjadinya pelanggaran Hukum oleh Notaris yakni dengan preventif fan kuratif, maka berdasarkan ketentuan diatas penulis mencoba mengidentifikasi kewenangan-kewenangan mana saja yang termasuk upaya pencegahan yang bersifat prefentif dan yang bersifat kuratif.

Kewenangan yang bersifat prefentif antara lain adalah hal yang diatur dalam pasal 70 huruf b, c, d, e, f dan h UUJN, Pasal 15 ayat (2) huruf $a, b, c$, e dan $f$, dimana kewenangan tersebut bersifat admnistratif yang lebih mengatur tentang cara prosedural dan protokol kenotariatan. Sedangkan kewenangan pencegahan yang bersifat kuratif yang diantara lain adalah hal-hal yang diatur dalam Pasal 70 huruf a dan huruf g UUJN, Pasal 15 ayat (2) huruf d yang mengatur tentang pengambilan tindakan terhadap dugaan-dugaan pelanggaran yang dilakukan oleh Notaris terhadap UUJN dan Kode Etik.

Keberadaan Majelis Pengawas Daerah Notaris sebagai ujung tombak Majelis Pengawas, yang utama adalah untuk melakukan pengawasan dan pencegahan terhadap penegakan kode etik Notaris dan pelakasanaan jabatan Notaris tersebut.Dalam hal ini Majelis Pengawas Daerah harus tanggap dalam menangani pelanggaran yang dilakukan oleh Notaris.Selain itu juga harus bersifat transparan dalam menangani setiap kasus pelanggaran yang terjadi, agar kewibawaan dan kualitasnya tetap terjadi dimata masyarakat.Keberadaan Majelis Pengawas daerah jangan sampai menimbulkan kesan sebagai lembaga yang berpihak kepada Notaris. Majelis Pengawasan Notaris harus bersungguh-sungguh menjadi lembaga independen dalam melaksanakan tugas pembinaan kepada Notaris (Wawancara dengan Majelis Pengawas Daerah Kota Padang, 4 Mei 2018). 
Fungsi pembinaan ditujukan agar yang diawasi yaitu Notaris selalu diingatkan untuk selalu memahami dan oleh karena itu karena mematuhi aturan baik yang hanya tercantum dan diatur dalam Kode Etik Notaris Maupun ketentuan dalam Peraturan Perundang-Undangan yang berlaku.Semua itu dilandasi oleh Undang-Undang atau Makna Sumpah Jabatan yang diucapkan dan disaksikan oleh saksi dunia yaitu Pejabat Pelaksana Sumpah dan para saksi yang khusus untuk didatangkan untuk itu.Tidak lupa bahwa sumpah Jabatan Notaris tersebut disaksikan oleh Allah SWT, Tuhan Yang Maha Esa, Maha Mengetahui dan Maha Mengawasi.Dalam suasana empati ini Notaris diharapkan mempunyai pertahanan diri untuk menangkal segala godaan dan iming-iming yang menggiurkan untuk menangkal segala sesuatu yang dapat membuat jatuhnya kehormatan dan martabat Notaris.

Berdasarkan hasil wawancara dengan salah seorang anggota Majelis Pengawas Daerah Kota Padang dari unsur pemerintah ibuk Desmawita, beliau mengatakan luas Daerah dan banyaknya jumlah Notaris merupakan suatu kendala atau penghambat untuk melakukan pengawasan dan pembinaan terhadap Notaris. Hal ini tentunya menjadi kurang efektif karena cukup memakan waktu dan tenaga dalam menjalankan tugas dan fungsi dari Majelis Pengawas Daerah Kota Padang.

Ada hal lain tentunya yang menghambat proses menjalankan tugas dari Majelis Pengawas Daerah Kota Padang beliau mengatakan bahwa Majelis Pengawas Daerah Notaris Kota Padang terdiri dari 3 (tiga) unsur didalamnya yaitu unsur dari Notaris, Akademisi dan Pemerintahan hal ini mejadi kendala tersendiri dikarenakan kesibukan masing-masing anggota dan hal ini berimbas pada waktu yang ada untuk menjalankan tugas dari Majelis Pengawas Daerah Notaris Padang dalam melakukan pengawasan dan pembinaan terhadap Notaris. Disamping waktu dan kesibukan dari para anggota, luas wilayah dan jumlah Notaris juga menjadi tolak ukur dalam melakukan pengawasan dan pembinaan secara efektif terhadap Notaris. Namun, terlepas dari itu setiap anggota Majelis Pengawas Daerah Kota Padang selalu menjalin komunikasi untuk memperlancar tugas dan kewenangan Majelis Pengawas Daerah Padang baik secara telepon maupun media social jika memang adanya laporan atau pengaduan seperti pelanggaran kode etik ataupun terkait UUJN dari masyarakat para anggota selalu melakukan koordinasi dengan ketua Majelis Pengawas Daerah Kota Padang untuk melakukan pembentukan Mejlis pemeriksa untuk dilakukan proses pemeriksaan atas laporan tersebut. 


\section{SIMPULAN}

Hasil penelitian menunjukkan bahwa faktor penyebab terjadinya pelanggaran hukum yang dilakukan oleh Notaris di Kota Padang adalah tidak adanya apresiasi dari Notaris terhadap sosialisasi yang dilakukan oleh Majelis Pengawas Daerah Kota Padang, dan masih adanya Notaris baru yang tidak mau berdisukusi atau bertanya terhadap Notaris lainnya yang sudah banyak pengalamannya. Dan Notaris suka menerima pekerjaan yang tidak sesuai dengan tanggal yang dibuatnya akta tersebut dan Notaris sering tidak bertatap muka langsung dengan klien. Berkaitan dengan hal tersebut maka dapat diinventarisasi alasan-alasan mendasar mengapa Notaris cenderung melakukan pelanggaran Hukum dan Kode Etik yaitu Pengaruh sifat kekeluargaan, Pengaruh jabatan, pengaruh konsumerisme, karena lemah iman.

Tindakan yang dilakukan oleh majelis pengawas Daerah terhadap Notaris yang melakukan pelanggaran hukum oleh Notaris di Kota Padang adalah dengan membentuk Majelis Pemeriksa untuk menjalankan proses pemeriksaan agar dapat membuktikan apakah Notaris tersebut melakukan pelanggaran atau tidak. Jika memang Notaris yang bersangkutan terbukti melakukan pelanggaran jabatan maka akan diberikan sanksi berupa peringatan tertulis kepada Notaris yang bersangkutan tidak mengulangi perbuatannya lagi dan jika mengulanginya lagi kasus pelanggaran jabatan dapat direkomendasikan ke tingkat Majelis Pengawas Wilayah dan Majelis Pengawas Pusat sehingga dapat dijatuhkan sanksi yang lebih berat seperti pemberhentian sementara.

Peran Majelis Pengawas Daerah Dalam Mencegah Terjadinya Pelanggaran Hukum oleh Notaris di Kota Padang,pertama dengan menerapkan pengawasan yang bersifat preventif yaitu pengawasan yang dilakukan sebelum adanya pelanggaran yaitu dengan melakukan sosialiasasi dan penyuluhan hukum. Represif yaitu pengawasan yang dilakukan sesudah dikeluarkannya keputusan/ketetapan pemerintah atau sesudah adanya pelanggaran yaitu Mejelis Pengawas Daerah dengan melakukan sosialisasi ketika melakukan sidang pelanggaaran hukum yang dilakukan oleh Notaris, sehingga bersifat korektif dan memulihkan sutau tindakan yang keliru, disebut juga pengawasan aposteriori. Selanjutnya, melakukan sosialisasi kepada pihak-pihak yang terkait dengan profesi Notaris yang berada dibawah kewenangannya. Sosialisasi ini bertujuan untuk agar pihak-pihak yang berhubungan langsung dengan profesi Notaris dapat lebih memahami tentang keberadaan lembaga pengawas yang baru dibentuk, mengenai kewenagannya dalam menjaga penegakan kode etik Notaris. 


\section{DAFTAR PUSTAKA}

Adjie, Habib, Meneropong khazanah notaris dan PPAT Indonesia: kumpulan tulisan tentang notaris dan PPAT. Jakarta: Citra Aditya Bakti, 2009.

Braithwaite, John, "Rules and principles: A theory of legal certainty." Austl. J. Leg, 2002.

Buchanan, John, Dominic Heesang Chai, and Simon Deakin. 2014. "Empirical analysis of legal institutions and institutional change: multiple-methods approaches and their application to corporate governance research." Journal of Institutional Economics.10.1:1-20.

Fauzi, Machmud, Kewenangan Majelis Pengawas Cerminkan Kelembagaan Notaris, 2008.

Habermas, Jürgen, Between facts and norms: Contributions to a discourse theory of law and democracy. John Wiley \& Sons, 2015.

Hardjasoemantri, Koesnadi, Hukum tata lingkungan (No. 1). Gadjah Mada University Press, 1994.

Kelsen, Hans, General theory of law and state. Routledge, 2017.

Koentjoro, Diana Hakim, Hakim Administrasi Hukum. Bogor: Ghalia Indonesia, 2004.

Marzuki, Peter Mahmud, Pengantar Ilmu Hukum, Cetakan Kedua, Jakarta: Kencana Prenada Media Group, 2009.

McConville, Mike, Research methods for law. Edinburgh University Press., 2017.

Muhammad, Abdulkadir, Etika Profesi Hukum. Jakarta: Citra Aditya Bakti, 2009.

Raitio, Juha, The principle of legal certainty in EC law. Vol. 64. Springer Science \& Business Media, 2003.

Salim, Haji Said, Teknik Pembuatan Akta Satu (Konsep Teoritis, Kewenangan Notaris, Bentuk dan Minuta Akta). Jakarta: Raja Grafindo Persada, 2015.

Salim, Haji Said \& Nurbani, Erlies Septiana. Penerapan Teori Hukum Pada Penelitian Disertasi dan Tesis. Jakarta: Raja Grafindo Persada, 2014.

Yudara, N.G, Notaris dan Permasalahannya (Pokok-Pokok Pemikiran di Seputar Kedudukan dan Fungsi Notaris Serta Akta Notaris Menurut Sistem Hukum Indonesia), Makalah disampaikan dalam rangka Kongres INI di Jakarta), Majalah Renvoi Nomor 10.34.III, Edisi 3, 2014. 
Dina Shabrina et al.

Halaman ini sengaja dikosongkan 